\title{
Peertechz
}

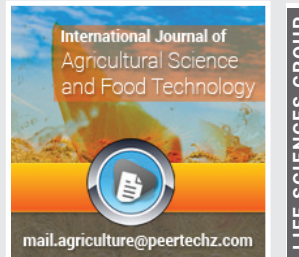

\section{Soil acid Management using Biochar: Review}

\section{Miheretu Bedassa*}

Ethiopian Institute of Agricultural Research (EIAR), Holeta Agricultural Research Center

(HARC), Natural Resource management process BOX 32, Holeta, Ethiopia
Received: 25 July, 2020

Accepted: 02 November, 2020

Published: 05 November, 2020

*Corresponding author: Miheretu Bedassa, Ethiopian Institute of Agricultural Research (EIAR), Holeta Agricultural Research Center (HARC), Natural Resource management process BOX 32, Holeta, Ethiopia, E-mail: miheretubedassa@gmail.com

Keywords: Biochar; Management; Soil acidity https://www.peertechz.com

\section{Check for updates}

\begin{abstract}
Soil acidity affects the growth of crops because acidic soil contain toxic levels of aluminum and manganese and characterized by deficiency of essential plant nutrients such as $\mathrm{P}, \mathrm{N}, \mathrm{K}, \mathrm{Ca}, \mathrm{Mg}$, and Mo. The management options to correct acid soils are, improve nutrient use efficiency, liming, application of organic materials, biocha, appropriate crop rotations, crop mixtures, use of varieties that tolerant to $\mathrm{Al}$ and $\mathrm{Mn}$ toxicity. Biochar application improves crop productivity through enhancing water holding capacity, cation exchange capacity (CEC), adsorption of plant nutrients and creates suitable condition for soil micro-organisms.
\end{abstract}

\section{Background and justification}

Soil acidification is a natural process, which can either be accelerated by the activity of plants, animals and humans or can be impeded by sound management practices. Industrial and mining activities can lead to soil acidification through acid drains resulting primarily from pyrite oxidation and from acid precipitation caused by the emission of sulfur $\left(\mathrm{SO}_{\mathrm{x}}\right)$ and nitrogen $\left(\mathrm{NO}_{\mathrm{x}}\right)$ gases. In areas that remain unaffected by industrial pollution, soil acidification is mainly caused by the release of $\mathrm{H}^{+}$ions during the transformation and cycling of $\mathrm{C}$, $\mathrm{N}$ and $\mathrm{S}$ in managed ecosystems. Soil acidification can exert itself in several ways: (a) increase of soil acidity or decrease of $\mathrm{pH}$, (b) decrease of base saturation, (c) unbalanced availability of elements in the root environment, or (d) decrease of the acid neutralizing capacity (ANC) of the soil [1].

Soil acidity affects the growth of crops because acidic soil contain toxic levels of aluminum and manganese and characterized by deficiency of essential plant nutrients such as $\mathrm{P}, \mathrm{N}, \mathrm{K}, \mathrm{Ca}, \mathrm{Mg}$, and Mo [2]. The cause of soil acidity could be the type of parent materials from which the soil are formed, leaching of base forming cations, continuous use of acid forming fertilizers such as Urea and DAP [3].

Soil acidity is one of the main factors that limit and prevent profitable and sustained agricultural productivity in many parts of the world. It is estimated that approximately $50 \%$ of the worlds' arable soils are acidic and may be subjected to the effect of aluminum (Al) toxicity of which the tropics and subtropics account for $60 \%$ of the acid soils in the world [4].

In Sub-Saharan African countries, soil fertility depletion is the fundamental biophysical cause for declining per capita food production [5]. This challenge will continue as population pressure increases and degradation of soil resources is aggravated. Reversing this trend lies in the enhancement of sustainable development of the agricultural sector; one of which is the management of good soil quality.

In Ethiopia $40.9 \%$ of the soil is acidic; from this $28 \%$ by moderately acidic soils ( $\mathrm{pH} 4.5-5.5)$ and $13 \%$ by strongly acidic soils $(\mathrm{pH}<4.5)[6]$.

The management options to correct acid soils are, improve nutrient use efficiency, increase crop production on acidic soils include liming, application of organic materials, biochar, appropriate crop rotations, crop mixtures and use of plant varieties tolerant to $\mathrm{Al}$ and $\mathrm{Mn}$ toxicity [7].

The potential of biochar as a soil amendment/soil acid management in agricultural fields is a recently recognized and yet it is underutilized technology. Biochar, (commonly known as charcoal or agrichar) is defined as a carbon(C) rich product derived from the pyrolysis of organic material at relatively low temperatures $\left(<700{ }^{\circ} \mathrm{C}\right)$ [8]. Biochar application improves crop productivity through enhancing water holding capacity, cation exchange capacity (CEC), adsorption of plant nutrients and creates suitable condition for soil micro-organisms [9]. 
According to FAO [10], charcoal production in Ethiopia is estimated to be 3.92 million tonnes. From the production of this, a minimum of $4 \%$ of the charcoal is non- marketable, 156,800 tonnes of biochar can be obtained.

Soil management by biochar increases nutrient availability, $\mathrm{pH}, \mathrm{CEC}$, crop yields and decreases risk of crop failure as well as opens new possibilities for cropping of high-value crops [11]. Despite the high potentials of biochar in Ethiopia, only very limited information exists [12].

Therefore, this review is carried out to investigate the effect of biochar on acidic soil.

\section{The chemistry of soil acidity}

Soil pH range: On the basis of their relative degree of acidity, soils are divided into several acidity or alkalinity classes, as shown in Figure 1. Such a classification enables the uses of proper terms for indicating acid-base conditions in soils.

Acid soils $(\mathrm{pH}<7)$ are common in humid regions. In these soils, the concentration of $\mathrm{H}^{+}$ions exceeds that of $\mathrm{OH}^{-}$ions.

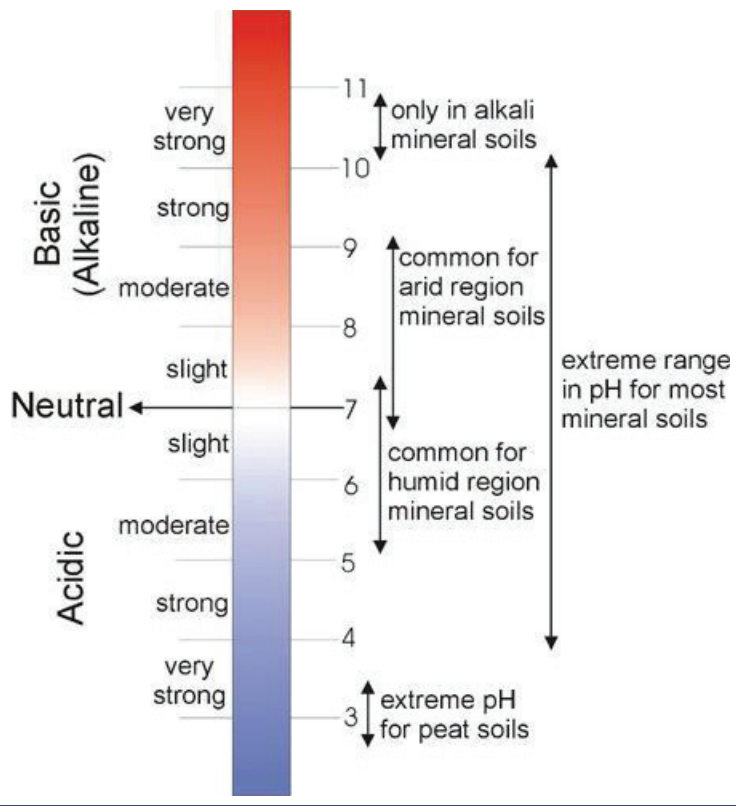

Figure 1: General Soil pH ranges and reaction classes of soils Source, Brady [13].

Most plants grow best in soils with a slightly acidic reaction. In this $\mathrm{pH}$ ranges nearly all plant nutrients are available in optimal amounts. Soils with $\mathrm{pH}<6$ will more likely be deficient of some of available nutrients for optimal plant growth. Calcium, magnesium, and potassium are especially deficient in acidic soils. In strongly and very strongly acidic soils, $\mathrm{Al}, \mathrm{Fe}, \mathrm{Mn}$ may exist in toxic quantities because of their increased solubility. In addition, these elements will react with phosphates to form insoluble phosphates, on phosphate retention and fixation [14].

Active versus potential acidity: A number of compounds contribute to the decomposition of acidic and basic soil reactions. Inorganic/organic acids, produced by the decomposition of organic matter, are common soil constituents that may affect soil acidity. The $\mathrm{H}^{+}$ions may be present in soils as adsorbed $\mathrm{H}^{+}$ ions in the soil solution. The portion of $\mathrm{H}^{+}$ions adsorbed by the clay complex becomes exchangeable $\mathrm{H}^{+}$ions. The exchangeable $\mathrm{H}^{+}$ions dissociate into free $\mathrm{H}^{+}$ions, and the amount adsorbed is usually in equilibrium with the amount free in solution. The chemical conditions created produce a chemical environment showing two types of soil acidities [14].

Active acidity is measured and expressed as soil pH. This is the type of soil acidity on which plant growth reacts. However, the tendency exists today to call this exchange acidity salt replaceable acidity which is especially to exchangeable $\mathrm{Al}^{+3}$ that can be replaced by un buffered salt solution (e.g. $\mathrm{KCl}$ ) [14].

However, this is most types of potential acidity because it requires hydrolysis of $\mathrm{Al}^{+3}$ to produce the $\mathrm{H}^{+}$ions that are the true source for soil acidity. Taken together, the active and potential acidity make up the total soil acidity. The free $\mathrm{H}^{+}$ions concentration of the soils solution at any particular time is relatively very small compared to the reserve or exchangeable $\mathrm{H}^{+}$concentration.

Residual acidity is defined as soil acidity that remains after active and exchangeable acidity has been neutralized [16] They believe that residual acidity is associated with aluminum hydroxide ions and with $\mathrm{Al}^{3+}$ and $\mathrm{H}^{+}$ions that are bound in non-exchangeable forms by organic matter and silicate clays. Kim [14] calls this "the remaining soil acidity that cannot be replaced by an unbuffered salts solution".

Exchangeable acidity: Exchangeable hydrogen (H) together with exchangeable Aluminum (Al) is known as soil exchangeable acidity. Soil acidity occurs when acidic $\mathrm{H}^{+}$ion occurs in the soil solution to a greater extent and when an acid soluble $\mathrm{Al}^{3+}$ reacts with water (hydrolysis) and results in the release of $\mathrm{H}^{+}$and hydroxyl $\mathrm{Al}$ ions into the soil solution [17]. Foth and Ellis [18] stated that during soil acidification, protonation increases the mobilization of $\mathrm{Al}$ and $\mathrm{Al}$ forms serve as a sink for the accumulation of $\mathrm{H}^{+}$. The concentration of the $\mathrm{H}^{+}$in soils to cause acidity is pronounced at $\mathrm{pH}$ values below 4 while excess concentration of $\mathrm{Al}^{3+}$ is observed at $\mathrm{pH}$ below 5.5 [19]. In strongly acidic conditions of humid regions where rainfall is sufficient to leach exchangeable basic cations, exchangeable $\mathrm{Al}$ occupies more than approximately $60 \%$ of the effective cation exchange capacity, resulting in a toxic level of aluminum in the soil solution. Generally, the presence of more than $1 \mathrm{ppm}$ of $\mathrm{Al}^{3+}$ in the soil solution can significantly bring toxicity to plants. Hence, the management of exchangeable Al is a primary concern in acid soils [20].

\section{Causes of soil acidity}

Major reasons for soils to become acidic are:

1. Rainfall and leaching

2. Acidic parent material

3. Organic matter decay

4. Harvest of high yielding crops

5. Removal of products from the farm or paddock

6. Inappropriate use of nitrogenous fertilizers 
The above causes of soil acidity are more easily understood when we consider that a soil is acid when there is an abundance of acidic cations, like hydrogen $\left(\mathrm{H}^{+}\right)$and aluminum $\left(\mathrm{Al}^{3+}\right)$ present compared to the alkaline cations like calcium $\left(\mathrm{Ca}^{2+}\right)$, magnesium $\left(\mathrm{Mg}^{2+}\right)$, potassium $\left(\mathrm{K}^{+}\right)$, and sodium $\left(\mathrm{Na}^{+}\right)$[21].

Rainfall and leaching: In conditions where rainfall exceeds, leaching during most of the year, the basic soil cations $\left(\mathrm{Ca}^{2+}\right.$, $\mathrm{Mg}^{2+}, \mathrm{K}^{+}$) are gradually depleted and replaced with cations held in colloidal soil reserves, leading to soil acidity. Soil acidity is really a high rainfall problem [22]. Clay soils often contain Fe and hydroxyl $\mathrm{Al}$, which affect the retention and availability of fertilizer cations and anions in acidic soils. Sandy soils are often the first to become acidic because water percolates rapidly, and sandy soils contain only a small reservoir of bases (buffer capacity) due to low clay and organic matter contents. Since the effect of rainfall on acid soil development is very slow, it may take hundreds of years for parent material to become acidic under high rain fall [21].

Parent material: Due to differences in chemical composition of parent materials, soils will become acidic after different lengths of time. Thus, soils that developed from granite material are likely to be more acidic than soils developed from calcareous shale or limestone [21].

Organic matter decay /Dissociation: While organic matter has many beneficial effects including improving soil structure, the increasing amount of organic matter may make the soil more acid. Decaying organic matter produces $\mathrm{H}^{+}$which is responsible for acidity. The carbon dioxide $\left(\mathrm{CO}_{2}\right)$ produced by decaying organic matter reacts with water in the soil to form a weak acid called carbonic acid. This is the same acid that develops when $\mathrm{CO}_{2}$ in the atmosphere reacts with rain to form acid rain naturally. Several organic acids are also produced by decaying organic matter, but they are also weak acids. Like rainfall, the contribution to acid soil development by decaying organic matter is generally very small, and it would only be the accumulated effects of many years that might ever be measured in a field [22].

Crop production and nutrient removal: Production of all agricultural products causes acidification. The way that plants take up nutrients results in a partitioning of acidity into the soil and alkalinity into the plant as dry matter. If a plant was naturally allowed to die and all parts returned to the soil, there would be no net change in $\mathrm{pH}$. As agriculture removes plant material from a paddock (as grain or pasture) less alkalinity is returned to the soil and the soil becomes more acidic [23].

Use of nitrogenous fertilizers: The use of $\mathrm{NH}_{4}^{+}$containing fertilizer over long period leads to soil acidification [24]. However; fertilizers vary in their acidifying effect. The acidifying effect of various $\mathrm{N}$ fertilizers followed this order: ammonium sulfate> ammonium nitrate>anhydrous ammonia>urea>calcium nitrate (Tables 1,2 ). The degree of acidity caused by a fertilizer is modified by soil characteristics, cropping systems and, environmental variables (Adams, 1984) [25]. Fertilizers may also cause acidity by increasing the export of basic cations relative to the unfertilized soil [24].

Table 1: Acid generating ammonium nitrifying reactions in soil.

Ammonium nitrate

Urea

Anhydrous ammonia.

Ammonium phosphate

Source: Kennedy (1992)

Table 2: Inorganic properties of biomass samples (wt.\% of the ash).

\begin{tabular}{l|l|l|l|l|l|l|l|l|l|l|l|l|} 
Sample & $\mathrm{Si}_{2} \mathrm{O}$ & $\mathrm{C}$ & $\mathrm{Al}_{2} \mathrm{O}_{2}$ & $\mathrm{~N}$ & $\mathrm{Fe}_{2} \mathrm{O}_{3}$ & Ash & $\mathrm{CaO}$ & $\mathrm{MgO}$ & $\mathrm{Na}_{2} \mathrm{O}$ & $\mathrm{KO}$ & $\mathrm{SO}_{3}$ & $\mathrm{P}_{2} \mathrm{O}$
\end{tabular}

\begin{tabular}{l|l|l|l|l|l|l|l|l|l|l|l|l|} 
Olive & 32.9 & 50.2 & 8.4 & 1.0 & 6.3 & 4.1 & 14.5 & 4.2 & 26.4 & 4.3 & 0.6 & 2.5 \\
\hline
\end{tabular}

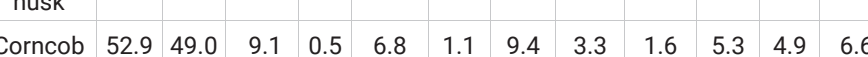

\begin{tabular}{|l|l|l|l|l|l|l|} 
Tea & 44.4 & 48.2 & 7.2 & 0.5 & 5.2 & 0 \\
\hline
\end{tabular}

\begin{tabular}{l|l|l|l|l|l|l|l|l|l|l|l|l} 
waste & 44.4 & 48.2 & 7.2 & 0.5 & 5.2 & 1.5 & 12.6 & 3.8 & 1.8 & 18.8 & 1.4 & 4.8 \\
\hline
\end{tabular}

Source: Ayhan Demirbas 2004 [31]

\section{Soil acidity in ethiopia}

The total area of Ethiopia is $\mathbf{1 1 1 . 8}$ million hectare out of these only 79 million of hectare is suitable for agriculture. Out of these about $40.9 \%$ of area is covered by strongly to weak acid soils. From these $28 \%$ moderately to weak acids with $\mathrm{pH}$ 5.8-6.7 and $13 \%$ covered by strong to moderate acidic soils with $\mathrm{pH}$ less than 5.5 [26]. The most strongly acidic soils are found in western and south western parts of Ethiopia, the central highlands, the high rainfall areas of north western part of the country. Nevertheless, moderately acidic soils ( $\mathrm{pH}$ 5.5- 6.5) are distributed through much of the rest of the country [27].

\section{Effect of soil acidity}

Major effects of soil acidification: Nutrient toxicity can occur in acid soils when the $\mathrm{pH}$ is $<4.8$ or lower. The two most important toxicities in acid soils are those of aluminum (Al) and manganese $(\mathrm{Mn})$ [28]. In strongly acid soils $(\mathrm{pHW}<4.3$ ) aluminum and manganese become more available in the soil solution and are harmful to plant roots. Aluminum toxicity is the most common and results in decreased production. on plant symptom on acidic soils and causes root stunting. Reduced root growth impedes nutrient and water [29].

\section{Production and composition of biochar}

produced by pyrolysis process: Biochar results from pyrolysis, a thermochemical conversion process for biomass materials such as crop residues, forestry waste, industrial by-product, municipal waste and animal manure,. Pyrolysis means breaking chemical bonds (lysis) with heat (pyro). The chemical bonds in biomass break during the pyrolysis process under low oxygen conditions (so the material does not just combust) and different compounds form and recondense into different end products. Together with the cracking reactions responsible for the formation of volatiles (gases and liquids), polycondensation reactions also occur which form biochar. Pyrolysis generally generates three products: a gas, a liquid, and a solid. Biochar is the solid [30].

\section{Uses of biochar}

The main purpose for the preparation of biochar is 
for carbon sequestration (stores carbon for long time), improved soil fertility, and reduces soil acidity for better crop production (IBI, 2012). It improves crop yield when applied as a soil amendment. Biochar can also be burned for energy and processed into activated charcoal for water purification [11].

\section{Methodology}

\section{Description of the study area}

The study was carried out at Koga which is Mecha District, West Gojam Zone of Amhara National Regional state, Ethiopia.. Nitosol is the dominant and soil type is moderately acidic [12].

Experimental setup: Three rates of biochar $\left(4,8,12 \mathrm{t} \mathrm{ha}^{-1}\right)$, one rate of lime $\left(2 \mathrm{t} \mathrm{h} \mathrm{a}^{-1}\right)$ and a control treatment (without biochar and lime) were combined in a factorial arrangement with three rates of chemical $\mathrm{N}$ and $\mathrm{P}$ fertilizer rates $(0,1 / 2$ and full recommended). A randomized complete block design (RCBD) with three replications was used [12].

Eucalyptus char from commercial sellers at Merawi town was collected and the bigger sized were crushed an fine grained in order to distribute them uniformly and increase the surf ace area of the char for better soil-char contact (Figure 2). Lime produced from Dejen lime mill enterprise was used [12].

\section{Soil sampling}

Prior to planting and before application of biochar and lime, composite soil samples were taken from the experimental sites using soil auger in $0-20 \mathrm{~cm}$ soil depth. At harvesting, soil samples from each treatment were taken and independently analyzed. Soil samples were air dried under shade, grounded by mortar \& pestle and sieved to pass through $2 \mathrm{~mm}$ mesh [12].

\section{Soil analysis}

The soil $\mathrm{p} \mathrm{H}$ was determined using glass electrode $\mathrm{pH}$ meter in 1:2.5 soil to water ratio in volume and exchangeable acidity $\left(\mathrm{Al}^{+3}\right.$ and $\left.\mathrm{H}^{+}\right)$were extracted with $\mathrm{KCl}$ solutions [32]. Total nitrogen analysis was done using the Kjeldahl method [33]. Available phosphorus was determined by Bray II method (Bray and Kurth 1945). Cation exchange capacity (CEC) was determined using the ammonium replacement method. Soil Organic Carbon (SOC) was determined following the wet digest ion method used by Walkley and Black [34] and organic carbon was converted to organic matter by multiplying with a coefficient of 1.724 .

\section{Result and discussion}

\section{Effect of biochar on soil properties}

Soil pH and exchangeable acidity: Addition of biochar from lower rate to higher rates production a reduction tends of exchangeable acidity. Incorporation of 12 tha $^{-1}$ biochar gave the lowest exchangeable acidity $(0.39 \mathrm{cmol} \mathrm{kg})$ followed by $2 \mathrm{t} \mathrm{ha} \mathrm{h}^{-1}$ lime $(0.44 \mathrm{cmol} \mathrm{kg})$, where the highest exchangeable acidity was $\left(0.60 \mathrm{cmol} \mathrm{kg}^{-1}\right)$ from the control plots (Figure 3) [12]. Lowering of exchangeable acidity and a rise in $\mathrm{pH}$ can provide a wide range of benefits in terms of soil quality, not ably by chemically improving the availability of plant nutrients, and in some cases by reducing the availability of detrimental elements such as $\mathrm{Al}$ [35].

Despite the long term potential impacts are to be seen, application of biochar and lime raised the soil pH substantially in one season. The higher $\mathrm{pH}$ values (6.17 and 5.9) were obtained on application of $2 \mathrm{t} \mathrm{ha}^{-1}$ lime and $12 \mathrm{t} \mathrm{ha}^{-1}$ biochar, respectively, whereas the lowest $\mathrm{pH}$ (5.38) was found on the control plot (Figure 4). Within one season $\mathrm{pH}$ increased by 0.79 and 0.52 units by application of $2 \mathrm{t} \mathrm{ha}^{-1}$ lime and $12 \mathrm{t} \mathrm{ha}^{-1}$ biochar, respectively from the control. Application of biochar at rates of 8 and $4 \mathrm{t} \mathrm{ha}^{-1}$ also showed 0.31 and 0.29 unit increment, respectively on soil $\mathrm{pH}$ from the same. It was apparent that the biochar applied in this study had a $\mathrm{pH}$ value of 8.43 , which is basic in reaction [12]. The alkalinity of most biochar can be beneficial to acidic soils, acting as a liming agent to increase $\mathrm{pH}$, and decrease exchangeable $\mathrm{Al}[11]$.

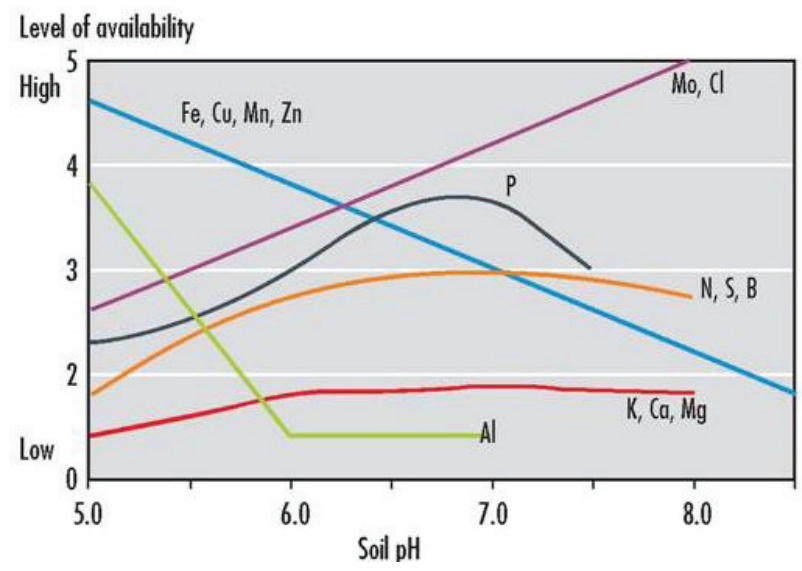

Figure 2: Relation between level of availability of different elements and soil $\mathrm{pH}$. Source: Goedert, et al. [15]

\section{Soil pH}

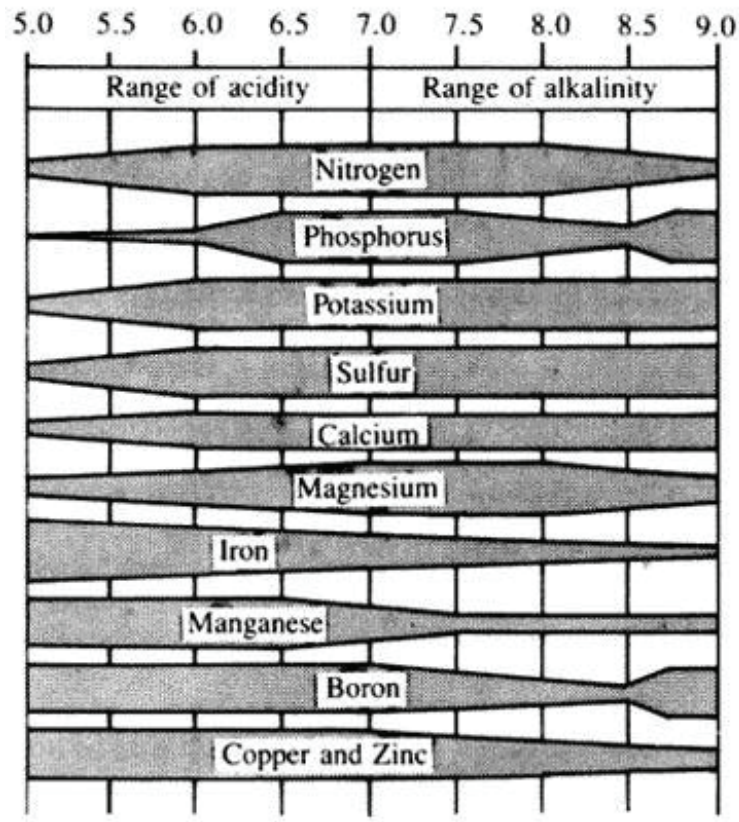

Figure 3: Effect of pH on nutrient availability, Source: Emil Truog, 1943-47. 


\section{Available P}

Soil available P increased after application of biochar and lime. As biochar rates increased, availability of $\mathrm{P}$ also increased. It increased from $12.75 \mathrm{ppm}$ without amendment to 18.92 and $17.50 \mathrm{ppm}$ after application of $12 \mathrm{t} \mathrm{ha}^{-1}$ biochar and $2 \mathrm{t} \mathrm{ha}^{-1}$ lime, respectively (Figures 5,6) [12].

An increase of available $\mathrm{P}$ on application of biochar could happen due to two reasons: the first one is that liming effect of biochar on acid soil that precipitates $\mathrm{Al}$ and $\mathrm{Fe}$ as $\mathrm{Fe}(\mathrm{OH})_{3}$ and $\mathrm{Al}(\mathrm{OH})_{3}$, thus increases availability of phosphorus in the soil system [36. According to Griffith [37] and Tisdale, et al. [36], under acid conditions, phosphorus is precipitated as Fe or Al phosphates. Maximum availability of phosphorus generally occurs in a $\mathrm{pH}$ range of 6.0 to 7.0. Miller and Donahue [38] also indicated that phosphorus is most available near $\mathrm{pH} 6.5$ for mineral soils. Tisdale, et al. [36] also discussed that $\mathrm{P}$ availability is at maximum in the $\mathrm{pH}$ range 5.5-6.0. Maintaining a soil $\mathrm{pH}$ in this range also favors the presence of $\mathrm{H}_{2} \mathrm{PO}_{4}{ }^{-}$which is more readily absorbed by the plant than $\mathrm{HPO}_{4}{ }^{2-}$ and occur at $\mathrm{pH}$ values above 7.0 [36] Figure 7.

The second reason is the presence of available phosphorus in biochar itself. Deluca, et al. [8] reported that biochar inherently contains a high content of soluble P salts formed during the charring of organic materials. Lehmann and Rondon [39] reviewed that an increase in availability of phosphorus after application of biochar could be due to the direct nutrient addition by the biochar and changes in soil microbial dynamics.. Chan, et al. [40] and Lehman, et al. [39] also discussed that application of biochar increased phosphorus concentration Figure 8.

The second reason is the presence of available phosphorus in biochar itself. Deluca, et al. [8] reported that biochar inherently contains a high content of soluble P salts formed during the charring of organic materials. Lehmann and Rondon [39] reviewed that an increase in availability of phosphorus after application of biochar could be due to the direct nutrient addition by the biochar and changes in soil microbial dynamics

Soil analysis result showed that application of fertilizer increased available P; $14.70 \mathrm{ppm}, 16.35$ and $17.30 \mathrm{ppm}$ were found on the application of $0,23 / 30$ and 46/60 (N/ $\left.\mathrm{P}_{2} \mathrm{O}_{5}\right) \mathrm{kg}$ $\mathrm{ha}^{-1}$ Table 3. Accordingly, application of biochar and lime with fertilizer and without fertilizer showed different values on available $\mathrm{P}$. Biochar rates and lime showed higher $\mathrm{P}$ at higher rates of fertilizer. As the rate of biochar and the rate of fertilizer increases, the $P$ value also increases [12].

This result indicates that the availability of the applied $\mathrm{P}$ fertilizer could be supported by the application of biochar and lime [12].

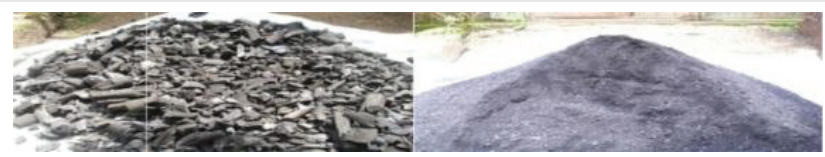

Figure 4: The state of charcoa I before (left) and after (righ t) crashed.

Source: Abewa, et al. [12]
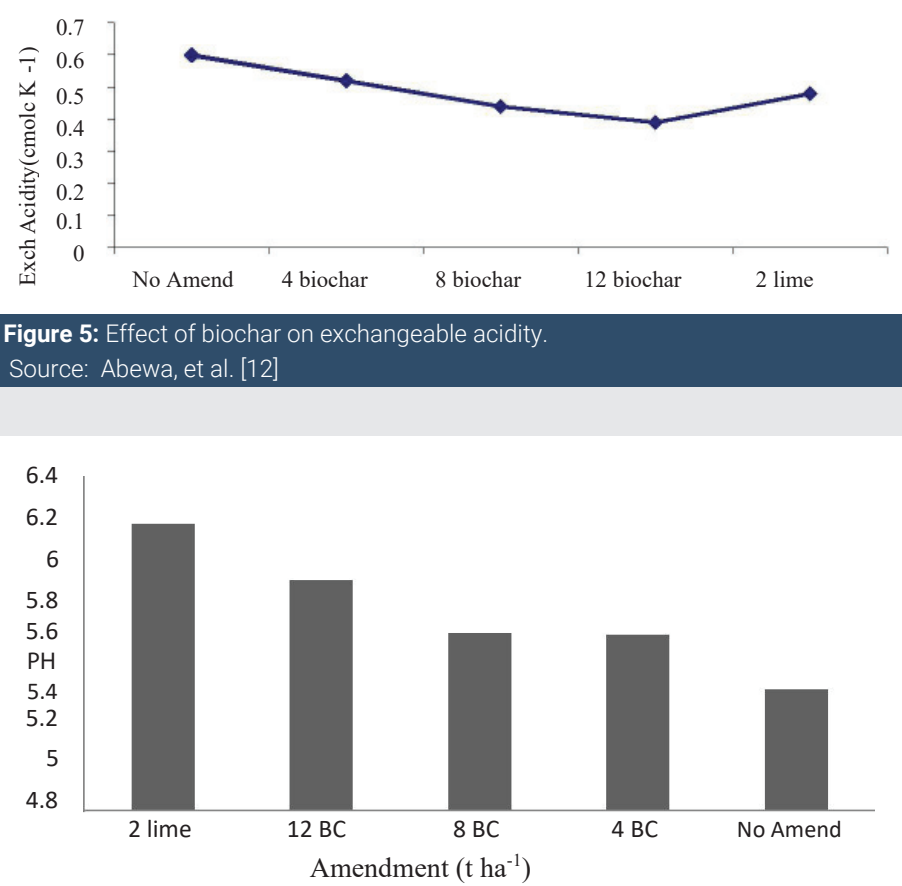

Figure 6: Effect of biochar and lime on soil pH

Source: [12].

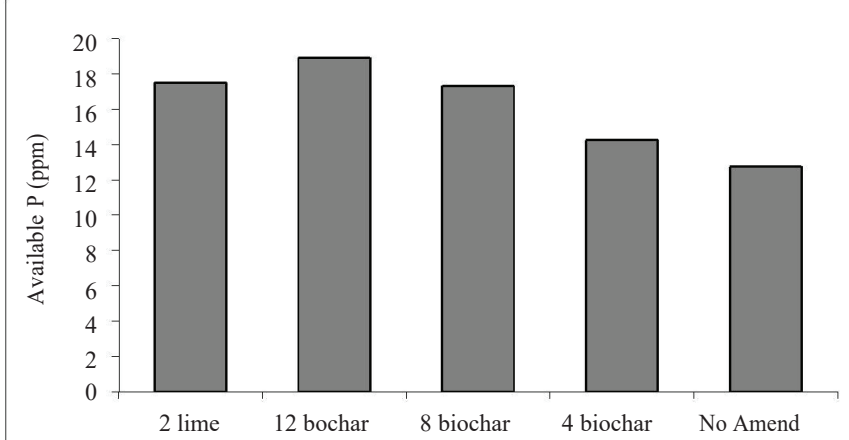

Figure 7: Effect of biochar and lime on available phosphorus.

Source: [12]

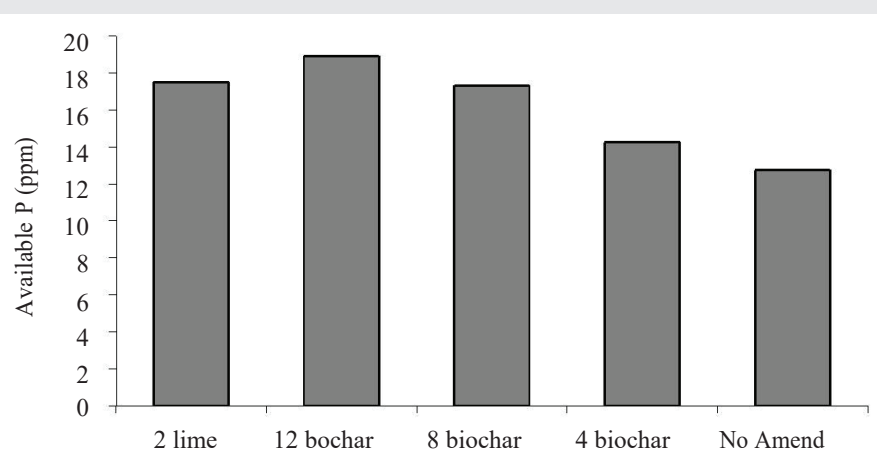

Figure 8: Effect of biochar and lime on available phosphorus.

Source: Abewa, et al. [12]

\section{Cation Exchange Capacity (CEC)}

The soil analysis result showed that incorporation of biochar and lime increased CEC of the soil. High CEC values (20.73 and 
$19.05 \mathrm{cmol} \mathrm{kg}^{-1}$ )were found on plots treated with $2 \mathrm{t} \mathrm{ha-1}$ of lime and $12 \mathrm{t} \mathrm{ha}^{-1}$ of biochar, respectively, whereas the lowest CEC (14.69 $\mathrm{cmol}_{\mathrm{c}} \mathrm{kg}^{-1}$ ) was found in the control plots (Figure 6). Generally, all biochar treatments showed higher CEC than the control one. Application of 4, 8 and $12 \mathrm{t} \mathrm{ha}^{-1}$ of biochar gave $6.13 \%, 11.25 \%$ and $29.68 \%$ CEC increment, respectively over the control. Edmunds (2012) also mentioned that biochar has high CEC [12].

\section{Organic carbon and total nitrogen}

Based on the soil analysis result, higher organic carbon (1.91\% and 1.84) were found on $2 \mathrm{t} \mathrm{ha}^{-1}$ lime and $12 \mathrm{tha}^{-1}$ biochar, respectively whereas the lowest content (1.66\%) was found from control plots (Table 1). The soil analysis data revealed that soil organic carbon increased by biochar application. This is due to the raise of soil $\mathrm{pH}$ in short period of time that favors soil microbes to decompose crop residues Table 4 [12].

Table 3: Effect of fertilizer on selected soil chemical properties.

\begin{tabular}{|c|c|c|c|}
\hline Fertilizer $\mathbf{N} / \mathbf{P}_{2} \mathbf{O}_{\mathbf{5}}\left(\mathbf{k g ~ h a}^{-1}\right)$ & $\mathbf{P H}$ & Total $\mathbf{N}(\%)$ & Available $\mathbf{P}(\mathbf{p p m})$ \\
\hline 0 & 5.73 & 0.17 & 14.70 \\
\hline $23 / 30$ & 5.77 & 0.18 & 16.35 \\
\hline $46 / 60$ & 5.75 & 0.18 & 17.40 \\
\hline
\end{tabular}

Source: [12].

Table 4: Effect of biochar and lime on soil chemical properties.

\begin{tabular}{|c|c|c|c|}
\hline \multicolumn{2}{|c|}{ Amendment } & OC (\%) & Total N (\%) \\
\hline $2 \mathrm{t} \mathrm{ha}^{-1}$ & Lime & 1.91 & 0.19 \\
\hline \multicolumn{2}{|c|}{$12 \mathrm{t} \mathrm{ha}^{-1}$ biochar } & 1.84 & 0.18 \\
\hline $8 \mathrm{t} \mathrm{ha}^{-1}$ & Biochar & 1.77 & 0.18 \\
\hline $4 \mathrm{t} \mathrm{ha}^{-1}$ & Biochar & 1.70 & 0.17 \\
\hline \multicolumn{2}{|c|}{ No Amendment } & 1.66 & 0.17 \\
\hline Source: $[12]$. & & \\
\hline
\end{tabular}

Application of biochar resulted in little differences on total nitrogen. Actually the study area has low total nitrogen [12]. Intensive cultivation as well as less crop residue management may contribute significant roles for the low level of total nitrogen. Application of biochar has no direct effect on nitrogen content of the soil, but it retains nitrogen from leaching [41]. The review of Clough, et al. [41] indicated that biochar has a high adsorption capacity of $\mathrm{NO}_{3}{ }^{-}$that prevents nitrogen leaching from the top soil. Kamayama, et al. [42] concluded that $\mathrm{NO}_{3}^{-}$was only weakly adsorbed to biochar, that it could be desorbed by water infiltration, and that the net result may be an increase residence time for $\mathrm{NO}_{3}{ }^{-}$in the soil. Due to its resistance to decomposition in soil, single applications of biochar can provide beneficial effects over several growing seasons in the field [11]. Therefore, biochar does not need to be applied frequently, as is usually the case for manures, compost, and synthetic fertilizers [12].

\section{Yield response to application of biochar, Lime and mi- neral fertilizers}

Significant teff yield variation was obtained by incorporating biochar and lime. The highest rate of biochar ( $\left.12 \mathrm{t} \mathrm{ha}^{-1}\right)$ resulted in better yield, while application of $2 \mathrm{t} \mathrm{ha}^{-1}$ lime resulted in a yield above application of $8 \mathrm{t} \mathrm{ha}^{-1}$ biochar and less than 12 $\mathrm{t}$ ha $\mathrm{a}^{-1}$ biochar applications (Table 3 ). In general, biochar and lime applications resulted in a significant yield increase $(\mathrm{P}<0.01)$ (Table 3). Application of $12 \mathrm{t} \mathrm{ha}^{-1}$ biochar and $2 \mathrm{t} \mathrm{ha}^{-1}$ lime gave 2.67 and $2.45 \mathrm{t} \mathrm{ha}^{-1}$ grain yield, respectively, while the lowest yield $\left(1.44 \mathrm{t} \mathrm{ha}^{-1}\right)$ was obtained from control plots. Incorporation of $12 \mathrm{t} \mathrm{ha}^{-1}$ biochar, $2 \mathrm{t} \mathrm{ha}^{-1}$ lime, $8 \mathrm{t} \mathrm{ha}^{-1}$ and 4 t ha ${ }^{-1}$ biochars had $85.66 \%, 70.63 \%, 37.79 \%$ and $19.97 \%$ yield advantage, respectively over the untreated plots [12].

Similar to grain yield, significant dry biomass yield variation was obtained by incorporation of biochar and lime. The highest rate of biochar $\left(12 \mathrm{t} \mathrm{ha}^{-1}\right)$ had a better biomass yield response than the lower rates. Application of $2 \mathrm{t} \mathrm{ha} \mathrm{h}^{-1}$ lime resulted in better yield than $8 \mathrm{t} \mathrm{ha}^{-1}$ but less than $12 \mathrm{t}$ $\mathrm{ha}^{-1}$ biochar. Application of $12 \mathrm{t} \mathrm{ha}^{-1}$ biochar and $2 \mathrm{t} \mathrm{ha}^{-1}$ lime gave 17.77 and $15.03 \mathrm{t} \mathrm{ha}^{-1}$ teff dry biomass yield, respectively whereas the lowest biomass yield (11.55 $\mathrm{t} \mathrm{ha}^{-1}$ ) was obtained from control treatment [12].

\section{Conclusions}

Application of biochar resulted in positive effect on soil chemical properties/soil acidic management. In highly acidic soils it may serve as a soil amendment by increasing the soil $\mathrm{pH}, \mathrm{P}$ availability, CEC and SOC in a sustainable manner. Biochar can enhance teff yield through improving the chemical and biological properties of the soil including organic carbon and other plant nutrients. This result also indicates application of biochar alone and in combination with fertilizer significantly increases yield. Significant yield increase was also achieved by combined application of biochar with chemical fertilizer, implying the role of biochar to improve fertilizer use efficiency.

\section{References}

1. van Breemen N (1991) Soil acidification and alkalisation. In "Soil Acidity" (B Ulrich, and M. E. Sumner, Eds.), 1-7. Link: https://bit.ly/2GmvgZe

2. Tisdale ST, Nelson WL, Beaton JD (1985) Soil Fertility and Fertilizers. 4th ed Macmillan Publishing Company, New York 499.

3. Cooke GW (1982) Fertilizer for maximum yield. Third edition. Collins Professional and Technical Books. London, UK.

4. Sumner ME, Noble AD (2003) Soil acidification: the world story. Handbook of soil acidity. Marcel Dekker, Inc. New York, NY., USA 128.

5. Sanchez PA, Sheperd S, Buresh AMN, Izac AU, Mokwunye FR, et al. (1997) Soil Fertility Replenishment in Africa. An Investment in Natural Resources Capital. 1-46. Link: https://bit.ly/3oRCmq3

6. Mesfin A (2007) Nature and Management of Acid Soils in Ethiopia. Addis Ababa, Ethiopia. Link: https://bit.ly/2HZOarf

7. Sanchez PA, Salinas JG (1981) Low input Technology for managing Oxisols and Ultisols in Tropical America. Adv Agron 34: 279-406. Link: https://bit.ly/2HSKjdD

8. Deluca TH, Mackenzie MD, Gundale MJ (2009) Biochar effects on soil nutrient transformations. In Lehmann J. and Joseph S. (Eds.). Biochar for environmental management: Science and Technology 251-270.

9. Lehmann J, Rillig MC, Thies J, Masiello CA, Hockaday WC, et al. (2011) Biochar 
effects on soil biota: A review. Soil biology and soilchemistry 43: 1812-1836 Link: https://bit.ly/3jZek9a

10. FAO (Food and Agricultural Organization of the United Nations). (2011) Highlights on wood and charcoal: 2004-2009", FAO orestry department data source: FAOSTAT-forest stat (vol. 12, January 2011). Link: https://bit.ly/35ZzP4p

11. Major J, Rondon M, Molina D, Riha SJ, Lehmann J (2010) Maize yield and nutrition during 4 years after biochar application to a Colombian Savanna oxisol. Plant and soil 333: 117-128. Link: https://bit.ly/328NoNR

12. Abewa A, Yitaferu B, Gselassie Y, Amare T (2013) Role of Biochar on Acid Soil Reclamation and Yield of Teff (Eragrostis tef [Zucc] Trotter) in Northwestern Ethiopia. Link: https://bit.ly/2TMMTET

13. Brady NC (1980) The nature and properties of soil, 8th Ed, NewYork.

14. Tan KH (2010) Principlesof soil environmental chemistry. CRC press. NewYork

15. Goedert WJ, Lobato E, Lourenco S (1997) Nutrient use efficiency in Brazilian acid soils: Nutrient management and plant efficiency. In: Plant-Soil Interactions at Low pH. Moniz, A.C. et al. (eds.). Brazilian Soil Science Society 97-104.

16. Brady NC, Weil RR (1996) The nature and properties of soils.12th edition. Prentice- Hall Inc. $449-453$

17. Brady NC, Weil RR (2002) The nature and properties of soils, 13th Ed. PrenticeHall Inc., New Jersey, USA. 960.

18. Foth HD, Ellis BG (1997) Soil fertility, 2nd Ed. Lewis CRC Press LLC., USA 290

19. Nair KM, Chamuah GS (1993) Exchangeable aluminum in soils of Meghlaya and management of $\mathrm{Al} 3+$ related productive constraints. $\mathrm{J}$ Indian Soc Soil Sci 4: 331-334. Link: https://bit.ly/3kTTSYu

20. Buol SW, Hole FD, McCracken RJ (1989) Soil genesis and classification, 3rd Ed.Ames, IA: The lowa State University Press. 446.

21. Jonhson CV (1914) Cause and effects of soil acidity.Oklahoma Cooperative Extension Facts sheets PSS-2239. Link: https://bit.ly/3jPq0el

22. Slattery B, Hollier C (2002) The Impact of Acid Soils in Victoria. Report for the Department of Natural Resources and Environment, Goulburn Broken Catchment Management Authority, North East Catchment Management Authority. Link: https://bit.ly/3mLoZFX

23. Munkovich P, Sanford J, Pate M (1998) Effects of grazing on plants and soil nitrogen relations of pasture-crop rotations. J Agric Res 49: 475-485. Link: https://bit.ly/3kTTxVI

24. Bolan N, Hedley T, White RE (1991) Process of soil acidification during nitrogen cycling with emphasis on legume based pastures. Plant and soil 134: 53-63. Link: https://bit.ly/2HSIT2N

25. Adams F (1984) Soil acidity and liming. American Society of Agronomy, Madison, WI.

26. Schlede H (1989) Distribution of acid soils and liming materials in Ethiopia Ethiopian Institute of Geological Surveys, Ministry of Mines and Energy. Addis Ababa, Ethiopia.

27. Taye B (2008) Estimation of Lime Requirement. Training Manual for Regional Soil Testing Laboratory Heads and Technicians. National soil Testing Center, Ministry of Agriculture and Rural Development.

28. Slattery WJ, Ridley AM, Windsor SM (1991) Ash alkalinity of animal and plant products. Australian Journal of Experimental Agriculture 31: 321-324. Link: https://bit.ly/2TKEFgq
29. Slattery WJ, Coventry DR (2000) Response of wheat, triticale, barley, and canola to lime on four soil types in north- eastern Victoria. Aust J Exp Agric 33: 609-618.

30. Hunt J, Duponte M, Sato D, Andrew K (2010) The Basics of Biochar; A Natural Soil Amendment. Soil and crop management-SCM 30: 1-6. Link: https://bit.ly/3jTzXYm

31. Ayhan D (2004) Effects of temperature and particle size on bio-char yield from pyrolysis of agricultural residues. Department of Chemical Engineering, Selcuk University, 42031 Konya, Turkey. Link: https://bit.ly/3mKXIsP

32. Sahilemedhin S, Taye B (2000) Procedures for Soil and Plant Analysis Technical Paper. National Soil Research Center, Ethiopian Agricultural Research Organization, Addis Ababa, Ethiopia.

33. Jackson ML (1958) Soil chemical analysis. New Jersey: Prentice Hall, Inc.

34. Van Reeuwijk LP (1992) Procedures for soil analysis (3rd ed.). Internationa soil reference and information center. Wageningen (ISRIC). The Netherlands.

35. Brady NC, Weil RR (2008) The Nature and Properties of Soils (14th ed.). New Jersey: Pearson Prentice Hall.

36. Tisdale S, Nelson W, Beaton J, Havlin J (2002) Soil fertility and fertilizers (5th ed.). Prentice-hall, inc., Englewood Cliffs, N.J.., USA.

37. Griffith B (2006) Essential role of phosphorus in plants.

38. Miller R, Donhue R (1997) Soil in our environment (7th ed.). Prentice-hall.

39. Lehmann J, Rondon M (2006) Bio-char soil management on highly-weathered soils in the humid tropics. In N. T. Uphoff et al. (Eds), Biological approaches to sustainable soil systems. Crc/Taylor \& Francis, Boca Raton. Link: https://bit.ly/2HU6C2C

40. Chan KY, Van Zwieten I, Meszaros I, Downie A, Joseph S (2007) Agronomic values of green waste biochar as a soil amendment. Australian Journal of Soil Research 45: 629-634. Link: https://bit.ly/3jQw0DF

41. Clough TJ, Condron LM, Kammann C, Müller C (2013) A review of biochar and soil nitrogen dynamics. gronomy 3: 275-293. Link: https://bit.ly/325rGu4

42. Kameyama K, Miyamoto T, Shiono T, Shinogi Y (2012) Influence of sugarcane bagasse derived biocharapplication on nitrate leaching in calcaric dark red soil. J Environ Qual 41: 1131-1137. Link: https://bit.ly/2TKNyGI

43. Abdenna D, Negassa C, Tilahun G (2007) Inventory of Soil Acidity Status in Crop Lands of Central and Western Ethiopia. "Utilisation of diversity in land use systems: Sustainable and organic approaches to meet human needs"

44. Bray RH, Kurtz LT (1945) Determination of total, organic and available form of phosphorous in soils. Soil Science 59: 39-45. Link: https://bit.ly/3jOtwpv

45. Emil T (1943) USDA Year book of Agriculture. 42.

46. Kennedy IR (1992) Acid Soil and Acid Rain. (2nd edition, John Wiley and Sons Inc.).

47. Lehmann J, Gaunt J, Rondon M (2006) Bio-char sequestration in terrestria ecosystems-a review. Mitigation and adaptation strategies for global change 11: 395-419. Link: https://bit.ly/3kRlhdC

48. Nigusssie T, Yared A (2010) Effect of Land Use/Land Cover Management on Koga Reservoir Sedimentation. Nile Basin Capacity Building Network. Cairo, Egypt. Link: https://bit.ly/3jPRSyT

Copyright: () 2020 Bedassa M. This is an open-access article distributed under the terms of the Creative Commons Attribution License, which permits unrestricted use distribution, and reproduction in any medium, provided the original author and source are credited. 